\title{
Work-Based Antipoverty Programs for Parents Can Enhance the School Performance and Social Behavior of Children
}

\author{
Aletha C. Huston, Greg J. Duncan, Robert Granger, Johannes Bos, Vonnie McLoyd, \\ Rashmita Mistry, Danielle Crosby, Christina Gibson, Katherine Magnuson, \\ Jennifer Romich, and Ana Ventura
}

\begin{abstract}
We assess the impact of the New Hope Project, an antipoverty program tested in a random assignment experimental design, on family functioning and developmental outcomes for preschool- and school-aged children $(N=913)$. New Hope offered wage supplements sufficient to raise family income above the poverty threshold and subsidies for child care and health insurance to adults who worked full-time. New Hope had strong positive effects on boys' academic achievement, classroom behavior skills, positive social behavior, and problem behaviors, as reported by teachers, and on boys' own expectations for advanced education and occupational aspirations. There were not corresponding program effects for girls. The child outcomes may have resulted from a combination of the following: Children in New Hope families spent more time in formal child care programs and other structured activities away from home than did children in control families. New Hope parents were employed more, had more material resources, reported more social support, and expressed less stress and more optimism about achieving their goals than did parents in the control sample. The results suggest that an anti-poverty program that provides support for combining work and family responsibilities can have beneficial effects on the development of school-age children.
\end{abstract}

\section{INTRODUCTION}

Economic policies affecting low-income families in the United States have been undergoing major transformations since the early 1980s. Unlike many areas of social policy, welfare policy has been informed by random assignment experiments testing the effects of policy variations on adult labor force participation, income, and welfare receipt (Friedlander \& Burtless, 1995; Gueron \& Pauly, 1991). Despite the fact that the targets of these policies are almost all single mothers, few of these studies have considered the impacts of program changes on family life and children.

In this paper, we describe the impacts of the New Hope Project on children's development and family functioning. New Hope was a 3-year demonstration experiment designed to test the effectiveness of an employment-based antipoverty program. For adults who were employed full time, it provided wage supplements sufficient to raise family income above the poverty threshold and subsidies for child care and health insurance. Project representatives provided advice and services to participants, and community service jobs were available for people who could not find market employment.

Because New Hope was tested with a rigorous random assignment experimental design, this study represents a strong test of the causal effects of the program on child development and family functioning. It offers information that is especially pertinent to public policy affecting the working and nonworking poor as states institute new programs in response to the 1996 Personal Responsibility and Work Opportunities Act.

\section{Conceptual Framework}

Direct effects of New Hope were expected on parent employment, family income and material wellbeing, child care, and health care. Because the program services were offered as a package, the separate effects of these components on children and family life cannot be identified with certainty, but existing literature on each of them informed the design of the study.

\section{Parent Employment}

Most of the parents in New Hope were female and single, therefore, "parental" employment was in fact maternal employment. Although increased employment could have both positive and negative effects on children's well-being (Hoffman, 1989), most of the available evidence suggests that children in lowincome families benefit from maternal employment. The positive effects of the income generated and

(C) 2001 by the Society for Research in Child Development, Inc. All rights reserved. 0009-3920/2001/7201-0020 
mothers' psychological well-being appear to outweigh the possible negative effects from decreased parental time and supervision (Desai, Chase-Lansdale, \& Michael, 1989; Zaslow \& Emig, 1997; Zaslow, Rabinovich, \& Suwalsky, 1991). Unemployment is often associated with more stress than employment, particularly for single mothers (McLoyd, Jayaratne, Ceballo, \& Borquez, 1994). Negative effects are more likely, however, if children are left alone or placed in inadequate child care; if mothers enter jobs with low complexity (i.e., routine, repetitive activities with little opportunity for initiative; Parcel \& Menaghan, 1997); or if mothers receive very low wages (Moore \& Driscoll, 1997). Several features of New Hope reduced the likelihood of these negative effects. Although many New Hope participants worked in low status jobs, some of which were probably low in complexity, their employment generated more economic benefits (i.e., earnings supplements, child-care and health care subsidies) than would typically be the case for individuals working in low-wage jobs.

\section{Income}

Increased family income is another possible reason for New Hope effects on children and families. Low family income, particularly chronic poverty, is related to children's health, intellectual functioning, academic achievement, social behavior, and psychological well-being, and to adult educational and economic attainment (Children's Defense Fund, 1994; Duncan \& Brooks-Gunn, 1997; Hill \& Sandfort, 1995; Huston, 1991; Korbin, 1992; McLoyd, 1998). There are current debates, however, about whether low income is the critical variable affecting developmental outcomes in poor families as opposed to such attributes as single-mother family structure, large family size, minority group membership, low ability and education levels, poor mental health, welfare receipt, and genetic predispositions (Duncan \& Brooks-Gunn, 1997; Huston, McLoyd, \& Garcia Coll, 1997; Mayer, 1997; Rowe \& Rodgers, 1997).

Experimental designs manipulating income permit strong causal inferences, but are rare. In four Income Maintenance experiments in the 1960s and 1970s, experimental families received a guaranteed minimum income. School performance and attendance were positively affected in some sites for elementary school-age children, but not for high schoolage adolescents. In two sites reporting rates of high school completion and advanced education, these were higher for the experimental than for the control group (Mallar \& Maynard, 1981; Maynard \& Murnane, 1979; Salkind \& Haskins, 1982).

\section{Child Care and Organized Activities}

Impacts of New Hope on children could also occur as the result of experience in formal child care and structured out-of-school activities. The New Hope child-care subsidy could be used for any licensed or certified care, but project representatives encouraged parents to use center-based care because it is reliable, and many low-income parents prefer center care when it is available and affordable (Phillips \& Bridgman, 1995; Quint, Polit, Bos, \& Cave, 1994).

The impact of child care on children's social and cognitive development depends in part on its quality, which can be defined by structural features (e.g., low ratios of children to adults, trained caregivers) and by process features (e.g., sensitive, responsive caregiving; Lamb, 1997). When quality is equivalent, formal, center-based care is associated with more advanced cognitive and language development than is homebased child care, perhaps because centers typically include at least some educational materials and activities (Lamb, 1997; NICHD Early Child Care Research Network, 2000; Yoshikawa, 1999). Centers are also likely to provide more reliable care, reducing instability. In one welfare reform experiment, parents in the experimental group were given access to centerbased care for their infants and young children while they participated in educational activities. There were no significant effects of center care, but there were negative effects of unstable care arrangements on school readiness (Bos \& Granger, 1999).

For older school-age children (roughly ages 9-12), many parents and children take advantage of such organized activities as team sports, youth clubs, lessons, and community centers to provide supervision after school. We expected that New Hope children would participate in such activities more than did control group children because their parents spent more hours at work and because their families had slightly more income to pay for associated costs (e.g., athletic equipment, musical instruments). Participation in formal after-school care programs that provide cognitive stimulation and positive adult interactions is associated with academic achievement and low levels of behavior problems, particularly among low-income children (Pierce, Hamm, \& Vandell, 1999; Posner \& Vandell, 1994, 1999). Children without adult supervision in the out-of-school hours are at risk for behavior problems and poor adjustment, particularly if they live in lowincome families or unsafe neighborhoods (Pettit, Bates, Dodge, \& Meece, 1999; Marshall et al., 1997). Children in New Hope families, particularly girls, were also expected to perform more household chores and to assume more responsibility for care of younger siblings. 
Health Care

New Hope might affect availability of health care through its insurance subsidies. Poor children are less apt to receive routine and preventive medical and dental care than are more affluent children, although the difference has declined with the expansion of Medicaid (Klerman, 1991).

\section{Parenting}

If the New Hope experience increased employment and income, these changes might affect children as a result of changes in parents' psychological wellbeing and parenting practices. A host of studies have found income and emotional support to be positively related to adult psychological well-being, which in turn is strongly linked to positive parenting and positive parent-child relationships (McLoyd, 1990, 1998). A few of the experiments designed to test interventions with single mothers in poverty included measures of parenting and child development (Job Opportunities and Basic Skills JOBS: Moore, Zaslow, Coiro, Miller, \& Magenheim, 1995; New Chance: Quint, Bos, \& Polit, 1997; Zaslow \& Eldred, 1998; and the Teenage Parent Demonstration Program: Aber, Brooks-Gunn, \& Maynard, 1995). There were relatively few effects, but those that did occur indicated increased warmth and reductions in use of harsh punishment.

\section{Sex Differences}

In the present study, we investigated child outcomes in three domains: school performance and motivation, social behavior (positive social behavior and behavior problems), and psychological well-being (perceived competence, peer relations, and anxiety). Girls generally perform better in school and have more positive social behavior and fewer behavior problems than do boys (Golombok \& Fivush, 1994). On the other hand, boys have equal or even slightly higher perceptions of their own abilities (Eccles, Wigfield, \& Schiefele, 1997) and score lower on verbal reports of anxiety (Reynolds \& Richmond, 1985).

Existing literature can be used to generate different predictions about the impact of New Hope on boys and girls. Boys' greater vulnerability to school and behavior problems might make them more subject to positive impacts of greater family resources, formal child care, and supervised activities. One recent investigation found that high-quality after-school care predicted first-grade school performance and absence of behavior problems primarily for boys (Pierce et al., 1999). In the New Chance experiment, teachers rated the social behavior of school-age boys whose mothers had been in the New Chance treatment 3 years earlier more favorably than that of controls, but girls in New Chance families displayed less favorable social behavior than controls according to teachers, parents, and observers. By contrast, preschool-aged boys in experimental families (who had been infants when their mothers participated in New Chance) had more behavior problems and less positive social behavior than did control boys, but there were no significant program-control differences for preschool girls (Quint et al., 1997).

On the other hand, some reviewers have concluded that maternal employment may have greater benefits for girls and greater risks for boys, although this pattern has not been found consistently for children in low-income families (Hoffman, 1989; Zaslow et al., 1991). Positive effects for girls may result partly from having an achieving maternal model, but lowincome mothers' jobs may not be very rewarding or attractive. Moreover, daughters may be expected to do household chores and care for siblings when their mothers work. Negative effects on boys could result from reduced parental supervision and monitoring, but the child-care subsidies in New Hope permit parents to provide supervision while they are working.

\section{The Present Study}

In this study, we report data collected 2 years after parents of children aged 1 through 10 years were randomly assigned to the New Hope Project or to a control group. This age range was chosen to include children in the preschool years and in middle childhood during the 2-year period. There is some evidence that family income is especially important during the preschool years (Duncan \& Brooks-Gunn, 1997), and the top of this age range coincided with the upper limit for the child-care subsidy.

What is especially attractive about studying the New Hope intervention is that it provides an experimental test of the impacts of a program that bundles together employment, income, child care, and health care, permitting us to make causal inferences about the impacts of this package of resources with more certainty than is possible from most naturalistic research. As the experiment involved only a single, bundled treatment, however, we are unable to assess distinct impacts of the intervention components.

We addressed the following questions. Did the program affect (1) children's educational progress and motivation, social development, and psychological well-being? (2) Did it affect parent employment; family material well being; patterns of child care, supervised activities, and health care? (3) Did it have an effect on parents' psychological well-being, parenting, and parent-child relations? 


\section{METHOD}

\section{Design and Sample}

New Hope Project

The New Hope Project was an experimental antipoverty demonstration program in Milwaukee, Wisconsin, that offered the following benefits to participants when they were employed 30 or more hours per week: (1) a wage supplement that ensured that net income increased as they earned more; (2) a child-care subsidy for any child under age 13, which could be used for any state-licensed or county-certified childcare provider, including preschool programs for young children and extended day programs for school-age children; (3) subsidized health insurance. The childcare and health-care subsidies were commensurate to those available to some families through the Aid to Families with Dependent Children (AFDC) program and Medicaid. The program provided case management services to assist participants in job searches and other needs. If participants could not find unsubsidized employment, they were offered access to a community service job at minimum wage that counted toward the hours needed for New Hope benefits. A detailed description of the program's implementation appears in Brock, Doolittle, Fellerath, and Wiseman (1997).

\section{Sample}

Eligibility for New Hope was limited to two zip code-defined neighborhoods in Milwaukee's poorest areas. Applicants for the program had to meet three criteria: They should be older than 18 , have an income at or below $150 \%$ of the poverty line, and be willing to work 30 or more hours a week. The 1,357 adult applicants were randomly assigned to either program $(n=$ $679)$ or control $(n=678)$ status. Members of both groups could be eligible for any federal or state public assistance programs; individuals in the experimental program also had access to New Hope benefits. The program operated in a strong economic environment: unemployment rates for Milwaukee County between 1994 and 1997, when the experiment was conducted, ranged from $6.5 \%$ to $5.3 \%$.

The sample for the Child and Family Study (CFS) reported here consisted of all adults who had at least one child between the ages of 1,0 and 10,11 when they applied for the program (program group $n=366$; control group $n=379$ ). An additional 67 Asian adults with children (primarily Hmong) were not included because of cultural and language differences that made the assessment tools inappropriate for them. At the point of the 24-month survey, the children were ages 3,0 through 12,11 . Up to two children in each family were chosen from those in the eligible age range to be the "focal children" of the survey. If there were more than two eligible children, focal children were chosen randomly except that preference was given to opposite-sex siblings. The baseline demographic characteristics of the sample are shown in Table 1.

\section{Data Sources}

Data were compiled from four sources. First, when they applied to the program and just prior to randomization, all participants completed a baseline demographic questionnaire. Second, an in-person survey with parents and children was conducted 2 years after baseline. Of the eligible 745 parents, $578(78 \%)$ responded; of these 578,335 , or $58 \%$, had two focal children. There were 913 focal children (447 in the program group): 334 of these children were aged 3-5 (163 in the program group) and 579 were aged 6-12 (284 in the program group). Interviews were conducted with 230 (98 of the program group) 6- to 8year-old children and 288 (151 in the program group) 9- to 12-year-old children. Third, administrative data on employment, earnings, receipt of food stamps and AFDC, and the Earned Income Tax Credit were gathered from State of Wisconsin records.

Fourth, with parent permission, questionnaires were mailed to teachers of school-age children. Parents granted permission for teachers to be contacted for 566 out of the 668 eligible children. Surveys were not sent to 19 of these children's teachers for a variety of reasons (e.g., the child was home schooled, or not in school at the time of the interview). The teachers were unaware of the purpose of the study and were informed only that the child was involved in a study about children and their families. Of the 547 surveys mailed to teachers, 424 were returned (response rate $=63.5 \%$ of total sample). Four of these were for children younger than age 5 , and were not included in analyses.

\section{Measures}

In Table 2, the principal measures for children and for adult well-being and parenting are summarized with information about number of items and reliability.

\section{Child Education and Aspirations}

Academic achievement and classroom conduct. Teachers of school-age children completed the Academic subscale of the Social Skills Rating System 
Table 1 Characteristics of the Child and Family Study Parent Sample at Baseline

\begin{tabular}{|c|c|c|c|}
\hline & \multicolumn{3}{|c|}{ Group } \\
\hline & $\begin{array}{l}\text { Full Sample } \\
(N=745)\end{array}$ & $\begin{array}{l}\text { Program } \\
(n=379)\end{array}$ & $\begin{array}{c}\text { Control } \\
(n=366)\end{array}$ \\
\hline \multicolumn{4}{|l|}{ Gender $(\%)$} \\
\hline Female & 89.8 & 89.1 & 90.5 \\
\hline Male & 10.2 & 10.9 & 9.5 \\
\hline Average age & 29.4 & 29.6 & 29.2 \\
\hline \multicolumn{4}{|l|}{ Race/ethnicity (\%) } \\
\hline African American, non-Hispanic & 55.1 & 57.4 & 52.8 \\
\hline Hispanic & 29.2 & 27.9 & 30.6 \\
\hline White, non-Hispanic & 12.5 & 10.7 & 14.3 \\
\hline Native American/ Alaskan Native & 3.2 & 4.1 & 2.4 \\
\hline \multicolumn{4}{|l|}{ Marital status $(\%)$} \\
\hline Never married & 62.1 & 62.0 & 62.3 \\
\hline Married, living with spouse & 10.5 & 11.2 & 9.8 \\
\hline Married, living apart & 10.3 & 9.8 & 10.8 \\
\hline Separated, divorced, or widowed & 17.0 & 16.9 & 17.2 \\
\hline \multicolumn{4}{|l|}{ Number of children in household (\%) } \\
\hline 1 & 25.3 & 24.0 & 27.7 \\
\hline 2 & 28.8 & 32.5 & 25.1 \\
\hline 3 or more & 45.9 & 44.5 & 47.2 \\
\hline \multicolumn{4}{|l|}{ Labor force status at baseline (\%) } \\
\hline Ever employed & 94.1 & 95.1 & 93.1 \\
\hline Ever employed full time & 82.0 & 82.2 & 81.8 \\
\hline \multicolumn{4}{|l|}{ Earnings in 12 months prior to baseline (\%) } \\
\hline None & 36.4 & 36.1 & 36.7 \\
\hline$\$ 1-\$ 999$ & 16.4 & 17.8 & 15.0 \\
\hline$\$ 1,000-\$ 4,999$ & 23.5 & 23.0 & 24.0 \\
\hline$\$ 5,000-\$ 9,999$ & 13.8 & 13.4 & 14.3 \\
\hline$\$ 10,000-\$ 14,999$ & 6.7 & 6.8 & 6.6 \\
\hline$\$ 15,000$ or above & 3.2 & 3.0 & 3.4 \\
\hline \multicolumn{4}{|l|}{ Public assistance status } \\
\hline \multicolumn{3}{|l|}{ Currently receiving AFDC, General Assistance, } & 80.5 \\
\hline \multicolumn{4}{|l|}{ Educational status } \\
\hline High school diploma or GED (\%) & 47.4 & 48.9 & 45.9 \\
\hline Highest grade completed in school (average) & 11.1 & 11.2 & 11.0 \\
\hline
\end{tabular}

(SSRS) (Gresham \& Elliott, 1990), rating the child in comparison to others in the same classroom on reading skill, math skill, intellectual functioning, motivation, oral communication, classroom behavior, and parental encouragement. Teachers also responded to the Classrooom Behavior Scale, rating conformity to classroom rules and routines (e.g., behaves so as not to disturb peers), ability to work and complete tasks independently (e.g., remains on task with minimal supervision), and ability to make transitions without becoming distracted (e.g., moves quickly to next activity) (Wright \& Huston, 1995). Children who had not been retained or received special education were classified as making normal school progress.

Aspirations and expectations. Children ages 6-12 were asked about their occupational aspirations (what job they would like to have) and expectations (what job they thought they would have) (Cook et al., 1996). Responses were coded for occupational prestige (Nakeo \& Treas, 1990). Educational expectations were assessed for children aged 9-12 by asking how sure they were that they would finish high school, go to college, and finish college (Cook et al., 1996).

\section{Child Social Behavior}

Positive social behavior. Both parents and teachers completed the Positive Behavior Scale (Quint et al., 1997). Its items include compliance/ self control (e.g., thinks before he/she acts, usually does what I tell 
Table 2 Summary of Measures Showing Respondent, Number of Items, Response Scale, and Reliability

\begin{tabular}{|c|c|c|c|c|}
\hline Construct/Measure & Respondent & $\begin{array}{l}\text { No. of } \\
\text { Items }\end{array}$ & $\begin{array}{l}\text { Response } \\
\text { Scale }\end{array}$ & Reliability \\
\hline \multicolumn{5}{|l|}{ Child Outcomes } \\
\hline \multicolumn{5}{|l|}{ Academic achievement and school conduct } \\
\hline Social Skills Rating System (SSRS) academic subscale & $\mathrm{T}$ & 10 & $1-5$ & .94 \\
\hline Classroom Behavior Scale & $\mathrm{T}$ & 12 & $1-5$ & .90 \\
\hline Normal school progress & $\mathrm{T}, \mathrm{P}$ & 2 & $1-2$ & NA \\
\hline \multicolumn{5}{|l|}{ Child aspiration and expectation } \\
\hline Occupational aspiration & $\mathrm{C}$ & 1 & $1-99$ & NA \\
\hline Occupational expectation & $\mathrm{C}$ & 1 & $1-99$ & NA \\
\hline Educational expectation & $\mathrm{C}$ & 2 & $1-5$ & .66 \\
\hline \multicolumn{5}{|l|}{ Child social behavior } \\
\hline Positive Behavior Scale & $\mathrm{T}, \mathrm{P}$ & 25 & $1-5$ & $.95, .91$ \\
\hline SSRS Total Problem Behavior, 3-5 & $\mathrm{P}$ & 10 & $1-5$ & .69 \\
\hline SSRS Total Problem Behavior, 6-12 & $\mathrm{T}, \mathrm{P}$ & 17,11 & $1-5$ & .77 \\
\hline Externalizing & $\mathrm{T}, \mathrm{P}$ & 6 & $1-5$ & $.92, .81$ \\
\hline Internalizing & $\mathrm{T}, \mathrm{P}$ & 5 & $1-5$ & $.78, .61$ \\
\hline Hyperactivity & $\mathrm{T}$ & 6 & $1-5$ & .88 \\
\hline Discipline problems & $\mathrm{T}$ & 1 & $1-5$ & NA \\
\hline \multicolumn{5}{|l|}{ Perceived competence } \\
\hline Cognitive competence, 6-8 & $\mathrm{C}$ & 6 & $1-4$ & .74 \\
\hline Physical competence, 6-8 & $\mathrm{C}$ & 6 & $1-4$ & .67 \\
\hline Academic competence, 9-12 & $\mathrm{C}$ & 6 & $1-4$ & .74 \\
\hline Athletic competence, 9-12 & $\mathrm{C}$ & 6 & $1-4$ & .54 \\
\hline Self worth, $9-12$ & $\mathrm{C}$ & 6 & $1-4$ & .74 \\
\hline \multicolumn{5}{|l|}{ Peer relationships } \\
\hline Loneliness \& social dissatisfaction, 6-8 & $\mathrm{C}$ & 16 & $1-3$ & .65 \\
\hline Loneliness \& social dissatisfaction, 9-12 & $\mathrm{C}$ & 16 & $1-5$ & .89 \\
\hline \multicolumn{5}{|l|}{ Anxiety } \\
\hline Manifest Anxiety Scale, 6-8 & $\mathrm{C}$ & 12 & $1-3$ & .70 \\
\hline Manifest Anxiety Scale, 9-12 & $\mathrm{C}$ & 13 & $1-5$ & .87 \\
\hline \multicolumn{5}{|l|}{ Parenting and Parent Well-Being } \\
\hline \multicolumn{5}{|l|}{ Material hardship } \\
\hline Mayer \& Jencks Scale & $\mathrm{P}$ & 6 & $1-2$ & NA \\
\hline \multicolumn{5}{|l|}{ Parent psychological well being } \\
\hline Rosenberg Self-Esteem Scale & $\mathrm{P}$ & 10 & $1-4$ & .84 \\
\hline Pearlin Mastery Scale & $\mathrm{P}$ & 7 & $1-4$ & .76 \\
\hline State Hope Scale & $\mathrm{P}$ & 6 & $1-4$ & .82 \\
\hline CES-Depression Scale & $\mathrm{P}$ & 20 & $1-4$ & .90 \\
\hline Social support & $\mathrm{P}$ & 2 & $1-2$ & .45 \\
\hline Time pressure & $\mathrm{P}$ & 2 & $1-5$ & .31 \\
\hline Stress & $\mathrm{P}$ & 1 & $1-5$ & NA \\
\hline Financial worry & $\mathrm{P}$ & 5 & $1-5$ & .82 \\
\hline \multicolumn{5}{|l|}{ Parenting } \\
\hline Reported warmth & $\mathrm{P}$ & 3 & $1-6$ & .72 \\
\hline Observed warmth & $\mathrm{O}$ & 2 & $1-3$ & .49 \\
\hline Control & $\mathrm{P}$ & 5 & $1-6$ & .78 \\
\hline Monitoring & $\mathrm{P}$ & 4 & $1-4$ & .46 \\
\hline Expectations for child education & $\mathrm{P}$ & 3 & $1-6$ & NA \\
\hline Positive relation to caregiver, $6-8$ & $\mathrm{C}$ & 9 & $1-3$ & .66 \\
\hline Positive relation to caregiver, $9-12$ & $\mathrm{C}$ & 12 & $1-5$ & .87 \\
\hline Negative relation to caregiver, $6-8$ & $\mathrm{C}$ & 3 & $1-3$ & .45 \\
\hline Negative relation to caregiver, 9-12 & $\mathrm{C}$ & 7 & $1-5$ & .66 \\
\hline
\end{tabular}

Note: In respondent column, $\mathrm{P}=$ Parent, $\mathrm{C}=$ Child, $\mathrm{T}=$ Teacher, $\mathrm{O}=$ Observer. In reliability column, numbers are Cronbach $\alpha$ s or, for 2-item scales, correlations. 
him/her), social competence and sensitivity (e.g., gets along well with other children, shows concern for other people's feelings), and autonomy (e.g., tries to do things for him/herself, is self-reliant).

Problem behavior. Both parents and teachers completed the externalizing and internalizing subscales of the SSRS (Gresham \& Elliot, 1990). Externalizing problems include aggression and lack of behavior control (e.g., "is aggressive toward people or objects," "has temper tantrums"). Internalizing problems include social withdrawal and excessive fearfulness (e.g., "appears lonely," "acts sad or depressed"). Teachers also completed the hyperactivity subscale (e.g., "is easily distracted" and "disturbs ongoing activities"), and reported how often they had to discipline the child for misbehavior. Because of time restrictions, parents completed the positive and problem behavior scales for only one of their children, but teachers were asked about all school-age children.

For both positive and problem behavior, the correlations between parents' and teachers' ratings were low, total positive behavior $r=.19$; externalizing $r=$ .19 ; internalizing $r=.12$. These low correlations may indicate that children's social behavior is contextspecific, or they may reflect different reporting biases by teachers and parents.

\section{Child Psychological Well-Being}

Perceived competence. The Pictorial Scale of Perceived Competence and Social Acceptance for Young Children (Harter, 1985) and the Self-Perception Profile (Harter \& Pike, 1984) were given to 6- to 8-yearolds and to 9- to 12-year-olds respectively. Both age groups received scales measuring perceived academic and athletic competence; the 9- to 12-year-olds also completed the global self-worth scale.

Peer Relationships. The Loneliness and Social Dissatisfaction Questionnaire measures the child's perceptions of peer relationships and friendships (Asher \& Wheeler, 1985; Cassidy \& Asher, 1992). For purposes of this report, high scores represent satisfaction with peer relationships.

Anxiety. Children's general anxiety was measured with an abbreviated version of the Revised Children's Manifest Anxiety Scale (RCMAS; Pela \& Reynolds, 1982; Reynolds \& Richmond, 1985). The items measured were physiological anxiety (e.g., have trouble going to sleep), worry / oversensitivity (e.g., worry a lot), and social concerns (e.g., other children are happier).

\section{Parent Employment and Material Resources}

Data on the number of quarter-years of employment (i.e., positive earnings) for the eight quarters fol- lowing random assignment came from the employerreported state Unemployment Insurance records. Because administrative records do not contain the number of hours worked, parents' retrospective reports of work hours were used to determine average weekly work hours. Total family income was computed from administrative records that provided information about earnings, the Earned Income Tax Credit, the New Hope earnings supplement, AFDC, and food stamps for the eight quarters following random assignment. Material hardship was measured by a scale containing items about whether the family had experienced unmet medical needs, unmet dental needs, spells without utility service, periods without health insurance, and physical problems with housing such as leaking pipes or exposed wires (Mayer \& Jencks, 1989).

\section{Child Care and Child Activities}

Child-care history. Parents reported the number of months that each child had spent in various childcare arrangements for the 2-year period since random assignment. These were classified as "formal care" if they were structured programs provided outside the home, including Head Start, preschool, nursery school, a child-care center, a school-based extendedday program before or after school, or any other child-care program not in someone's home. For the most frequently used arrangement, parents were asked how many children and how many adults were in the child's group. Arrangements in the child's home or another person's home were classified as "home-based care."

Child time use: Activities and chores. Parents were asked how often 6- to 12-year-old children had participated in five organized or structured activities involving adult supervision (e.g., sports, lessons, club/ youth group activities), three activities not involving adult supervision (reading, homework, informal sports), and five household chores (e.g., clean their rooms, help with younger siblings) during the past year. Children ages 9 to 12 were asked about the frequency of these activities during the last year (yes or no) and during the past week ( $1=$ not at all; $4=$ every day). They were also asked how often they had done five activities with an adult (e.g., going shopping, doing homework, playing games). Using questions from the National Household Education Survey, researchers asked parents how often all children watched television on weekdays and weekends.

\section{Health Care}

Parents reported any type of insurance they had had and whether there were periods since baseline in 
which they and their families were uninsured. For each focal child, they were asked whether the child had a regular health-care provider who knew the child's health history; whether that provider was a hospital emergency room, clinic, doctor's office, or health center; and whether the provider would give medical advice by phone. They were also asked how recently the child had seen a health-care professional and a dentist, and, for children under 6 , whether immunizations were complete.

\section{Parent Psychological Well-Being}

Three scales measured relatively stable personality dispositions. The Rosenberg Self-Esteem Scale (Rosenberg, 1979) has self-evaluative items (e.g., "On the whole, I am satisfied with myself"). The Pearlin Mastery Scale (Pearlin, Lieberman, Menaghan, \& Mullan, 1981 ) is intended to measure external locus of control (e.g., "There is really no way I can solve some of the problems I have"). Depression was assessed using the Center for Epidemiological Studies-Depression (CES-D) scale; Radloff, 1977); this is a screening instrument that has been used in many large-scale projects with low-income adults.

The remaining scales were designed to measure aspects of well-being that might be somewhat more responsive to changes in social context and economic circumstances. The State Hope Scale (Snyder et al., 1996) assesses hope about achieving goals (e.g., "I am meeting the goals I set for myself"). Perceived social support of the kind provided by New Hope was assessed by asking whether or not the person had received programmatic advice or assistance and whether or not the person had received emotional support or counseling (yes or no) in the previous two years. Time pressure was assessed by questions about how often people felt rushed in general and how often they had extra time. Stress was assessed with an item asking how often the respondent had felt stressed in the last month. The calculated score contrasted much or almost all of the time versus other responses. Financial worry questions asked how much the person worried about paying bills, job security, having medical coverage, paying for food, affording adequate housing, and general financial health.

\section{Parenting}

Reported parental warmth contained items from the evaluation of the Canadian Self-Sufficiency Project (SSP) (e.g., frequency of praise, special activities; Statistics Canada, 1995). Observed warmth consisted of observational items from the HOME measure (Cald- well \& Bradley, 1984) — whether the parent conveyed positive feelings about the child and spontaneously praised the child's good qualities. Control included items about consistency and effectiveness of discipline (e.g., how often the child ignores the parent's punishment; Statistics Canada, 1995). Parental monitoring items, given for children ages 6-12, ask parents about their familiarity with the child's friends and their knowledge of the child's whereabouts and companions when the child is away from home.

Parent motivation for child's education. Parents were asked how far they would like for their child to go in school (aspiration), how far they expected the child to go (expectation), and the minimum school attainment that they would consider satisfactory (minimum standard; Medrich, Roizen, Rubin, \& Buckley, 1982). Children ages 9-12 were asked how sure they were that their parent expected them to complete high school, attend college, and graduate from college.

Child's perceived relationship with caregiver. Children aged 6-12 were asked about their positive relationships (e.g., "Your parent spends a lot of time talking with you") and negative relationships ("Your parent argues with you a $\left.\operatorname{lot}^{\prime \prime}\right)$ with their primary caregiver (McLoyd et al., 1994). The versions used for children aged 6-8 differed slightly from those used for children aged 9-12.

\section{Analysis Procedures}

The reliabilities for measures of child outcomes, parent well-being, and parenting are shown in Table 2. Except where noted, measures of the same construct were positively and significantly correlated with one another.

We estimated program impacts by regressing (using Ordinary Least Squares, OLS) each of our measures on a dummy variable representing the family's experimental status in the program plus the following variables, obtained when adults applied for New Hope: having a high school diploma or GED; gender of the parent reporting; parent age; race/ethnicity; having a child under the age of 2 years; having more than three children; having received welfare in the prior year; receiving AFDC in family of origin; having a car; having ever been employed full-time; neighborhood (north side or south side); current employment status; and earnings in the year prior to random assignment. If the impacts were not estimated separately by gender, we controlled for the sex of the child as well. These baseline covariates are included in our regressions to increase the precision of the experimental/ control contrasts. We also investigated whether program impacts were moderated by a number of 
baseline covariates and report instances of significant interactions.

The coefficient on the experimental status variable captures the program impacts. Two-tailed tests with an alpha of .10 were used. This alpha level is equivalent to a one-tailed test at $p<.05$, which is appropriate for the majority of program effects that were predicted, but leaves open the possibility of detecting unpredicted effects as well. Differences in program impacts for boys and girls, children of different ages, and parents who were employed full-time or not at baseline were tested using the HT statistic. ${ }^{1}$ Where these differences were significant, they are reported. We used the STATA software package to estimate Huber-White standard errors (Huber, 1967; White, 1980, 1982) to adjust for the fact that the error terms for children within the same family are not likely to be independent.

The tables contain the regression-adjusted means of the experimental and control groups, the difference between experimental and control groups with a designation of the statistical significance of the estimated experimental effect, and the effect size, which expresses the experimental effect as a fraction of the standard deviation.

One noteworthy issue is why we estimate our model of program impacts with a series of separate regressions rather than with a mediated structural equations model. We do so to capitalize to the extent possible on the experimental nature of the data. Randomization occurred with respect to receipt of the bundle of program services and not on the basis of mediators such as maternal employment or mental health. Only by treating each outcome and mediator in a separate experimental/control regression is the purity of the experimental design maintained.

\section{RESULTS}

\section{Use of Benefits}

Most families assigned to the New Hope group received at least some of its benefits. During the 2-year period following random assignment, $79.2 \%$ of the participants received an earnings supplement for an average of 9.3 months; $46.7 \%$ used the New Hope child-care subsidy for an average of 11.6 months; and $39.9 \%$ used the New Hope health insurance subsidy for an average of 9.1 months. Reasons for not receiv-

\footnotetext{
${ }^{1}$ The HT statistic is the weighted sum of squares of the effect size estimates for the subgroups about the weighted mean effect. If the effects are identical, this statistic has a $\chi^{2}$ distribution. Thus, a $\chi 2$ test was used to determine whether estimated effects for different subgroups were statistically significantly different from one another (Greenberg, Meyer, \& Wiseman, 1993, p. 20).
}

ing benefits included ineligibility (they were not employed full time or their earnings were too high), service available elsewhere (e.g., Medicaid), or absence of need (e.g., family members provided child care). For people receiving benefits, the average monthly amounts were $\$ 126$ for the wage supplement, $\$ 689$ for the child-care subsidy, $\$ 281$ for the New Hope HMO, and $\$ 84$ for employer's health insurance. Both program and control groups also received other benefits. For example, at the 24-month survey, $24 \%$ of program families and $29 \%$ of control families received AFDC; $46 \%$ of program families and $52 \%$ of controls received food stamps.

\section{Impacts on Children}

The first question was, did the program affect children's educational progress and motivation, social development, and psychological well-being?

\section{Children's Educational Achievement and Aspirations}

Most of the impacts of New Hope on children's educational achievement and aspirations were greater for boys than for girls. Although the main effect of the program was significant for academic achievement as measured by the SSRS Academic subscale $(p<.05$, effect size $=.25$ ), program impacts differed by gender for teacher-reported classroom behavior, HT $=4.12, p<$ .05 , children's occupational aspirations, HT $=4.11$, $p<.05$, children's expectations to attend college, $\mathrm{HT}=$ $5.76, p<.05$, and children's expectations to finish college, $\mathrm{HT}=3.22, p<.10$. Although the sex differences in program impacts were not significant for the Academic subscale or occupational expectations, the patterns were similar to those on the other measures.

The impacts for boys and girls are shown in Table 3. Boys in New Hope program families scored significantly higher than did boys in control families on almost all measures of educational progress and motivation. Boys in the program group scored .33 of a standard deviation higher than boys in control families on the SSRS Academic subscale and .38 of a standard deviation higher on classroom behavior. New Hope boys were more likely to expect to attend and complete college, and had higher occupational aspirations and expectations than did control group boys. There were no significant differences between girls in New Hope families and girls in control families on any of the education and aspiration measures.

The sex difference in the impact of the New Hope program should be evaluated in light of the absolute differences between girls and boys on academic performance and classroom behavior. Girls generally were doing better in school and had better study 


\begin{tabular}{|c|c|c|c|c|c|c|c|c|c|c|}
\hline \multirow[b]{3}{*}{ Outcome } & \multicolumn{5}{|c|}{ Boys } & \multicolumn{5}{|c|}{ Girls } \\
\hline & \multicolumn{2}{|c|}{ Group } & \multirow[b]{2}{*}{ Difference } & \multirow{2}{*}{$\begin{array}{c}\text { Effect } \\
\text { Size }\end{array}$} & \multirow[b]{2}{*}{$n$} & \multicolumn{2}{|c|}{ Group } & \multirow[b]{2}{*}{ Difference } & \multirow{2}{*}{$\begin{array}{c}\text { Effect } \\
\text { Size }\end{array}$} & \multirow[b]{2}{*}{$n$} \\
\hline & Program & Control & & & & Program & Control & & & \\
\hline \multicolumn{11}{|l|}{ Education and Aspiration } \\
\hline \multicolumn{11}{|l|}{ Teacher report } \\
\hline SSRS academic subscale & 3.27 & 2.95 & $.32^{*}$ & .33 & 208 & 3.43 & 3.31 & .12 & .12 & 208 \\
\hline Classroom behavior & 3.70 & 3.30 & $.40^{*}$ & .38 & 208 & 4.10 & 4.10 & 0 & -.02 & 208 \\
\hline Retained, special education $(\%)$ & .40 & .50 & -.10 & -.20 & 208 & .40 & .40 & 0 & .02 & 208 \\
\hline \multicolumn{11}{|l|}{ Child report } \\
\hline Expects to attend college & 4.33 & 3.76 & $.57^{*}$ & .49 & 137 & 4.03 & 4.18 & -.15 & -.13 & 150 \\
\hline Expects to finish college & 4.09 & 3.50 & $.60^{*}$ & .46 & 137 & 3.94 & 3.93 & .01 & .01 & 150 \\
\hline Occupational aspirations & 59.23 & 54.18 & $5.05^{*}$ & .29 & 241 & 56.42 & 57.87 & -1.45 & -.08 & 251 \\
\hline Occupational expectations & 58.23 & 54.09 & $4.14^{+}$ & .24 & 241 & 57.23 & 56.41 & .80 & .05 & 251 \\
\hline \multicolumn{11}{|l|}{ Positive social behavior } \\
\hline Teacher report-total & 3.62 & 3.29 & $.33^{* *}$ & .50 & 208 & 3.75 & 3.72 & .03 & .05 & 208 \\
\hline Parent report—total & 3.95 & 3.87 & $.08^{+}$ & .22 & 292 & 3.95 & 4.03 & -.08 & -.17 & 271 \\
\hline \multicolumn{11}{|l|}{ Problem Behavior } \\
\hline Teacher report - total & 2.30 & 2.60 & $-.30^{* *}$ & -.48 & 208 & 2.22 & 2.10 & .13 & .21 & 208 \\
\hline Externalizing & 2.07 & 2.50 & $-.43^{* *}$ & -.51 & 208 & 2.07 & 1.85 & $.22^{*}$ & .27 & 208 \\
\hline Internalizing & 2.20 & 2.33 & -.14 & -.22 & 208 & 2.26 & 2.22 & .04 & .07 & 208 \\
\hline Hyperactivity & 2.64 & 2.95 & $-.31^{*}$ & -.39 & 208 & 2.35 & 2.23 & .11 & .14 & 208 \\
\hline Discipline actions & 2.87 & 3.30 & $-.43^{*}$ & -.30 & 208 & 2.39 & 2.02 & $.37^{*}$ & .26 & 208 \\
\hline \multicolumn{11}{|l|}{ Parent report-total } \\
\hline 3 to 5 year-olds & 4.49 & 4.70 & -.20 & -.19 & 128 & 4.57 & 4.61 & -.03 & -.03 & 109 \\
\hline 6 to 12 year-olds & 4.57 & 4.84 & -.27 & -.22 & 164 & 4.76 & 4.52 & .23 & .19 & 161 \\
\hline
\end{tabular}

${ }^{*} p<.05 ;{ }^{* *} p<.01 ;{ }^{+} p<.10$. All two-tailed.

skills than did boys. It appears that the New Hope program brought boys' levels of academic performance and study skills closer to the typical levels for girls in both groups.

Positive Social Behavior and Behavior Problems

New Hope also had positive effects on social behavior, primarily for boys. The program impacts differed by sex for teacher-rated positive social behavior, $H T=5.15, p<.05$, parent-rated positive social behavior, $H T=5.03, p<.05$, teacher-rated total problem behavior, $H T=12.17, p<.001$, externalizing, $H T=$ $14.72, p<.001$, hyperactivity, $H T=6.94, p<.01$, and disciplinary actions, $H T=8.29, p<.001$.

Both parents and teachers rated New Hope boys higher than control group boys on total positive behavior (see Table 3). The effect sizes shown in Table 3 indicate that New Hope boys scored .50 of a standard deviation above control group boys on teacher reports. Neither teachers nor parents rated program group girls significantly differently than they rated control group girls.
Teachers reported on the SSRS that boys from experimental families had fewer problem behaviors than did control boys. Program group boys' scores on total behavior problems were almost one half of a standard deviation lower than those of control group boys. The difference was significant for the total score and for the externalizing and hyperactivity subscales. Teachers also reported fewer disciplinary actions for New Hope boys than they did for boys in the control group. That is, New Hope program boys were less disruptive, aggressive, and hyperactive in school than were control family boys (see Table 3 ). There were no program-control differences in parent ratings.

For girls, there was not a significant program effect on total behavior problems but, contrary to prediction, teachers rated program girls slightly higher than control girls on the externalizing subscale of the SSRS, and they reported more disciplinary actions for program than for control group girls (Table 3 ).

Again, the sex differences in program impacts occurred in the context of more positive scores overall for girls than for boys. Teachers and parents rated girls higher on positive social behavior, $F(1,389)=$ 
$19.63, p<.001$ for teachers, and $F(1,541)=4.65, p<$ .05 for parents. Teachers rated girls much lower than they did boys on behavior problems, $F(1,389)=$ $21.01, p<.001$.

\section{Children's Psychological Well-Being}

Different versions of the measures of perceived competence, friendship, and anxiety were administered to children aged $6-8$ years and $9-12$ years, so the two age groups were analyzed separately. Reliabilities for younger children were generally low, so experimental effects were unlikely to be detected. There were no program main effects or interactions on these measures for either age group.

\section{Impacts on Family Resources and Child Care}

The second research question concerns impacts on parent employment, family material well-being, patterns of child care, children's participation in supervised activities, and health care.

\section{Employment}

Impacts on employment and material well-being are shown in Table 4. Parents in New Hope were employed for more time than were parents in the control group. Approximately $30 \%$ of the sample members were employed full-time ( $30+$ hours) at baseline. The program did not significantly increase the levels of employment for those already working at least 30 hours a week, but it did increase employment for people who were not employed full-time at baseline (see Bos et al., 1999).

Impacts on Family Income and Material Hardship

The average income from all sources was higher for families in the program group than for those in the

Table 4 Impacts on Employment, Income, and Material Hardship

\begin{tabular}{|c|c|c|c|c|c|}
\hline \multirow[b]{2}{*}{ Outcome } & \multicolumn{2}{|c|}{ Group } & \multirow[b]{2}{*}{ Difference } & \multirow{2}{*}{$\begin{array}{l}\text { Effect } \\
\text { Size }\end{array}$} & \multirow[b]{2}{*}{$n$} \\
\hline & Program & Control & & & \\
\hline $\begin{array}{l}\text { Quarters of } \\
\text { employment }\end{array}$ & 6.04 & 5.32 & $.72^{* *}$ & .27 & 744 \\
\hline Hours employed & 2,970 & 2,729 & $242^{*}$ & .16 & 582 \\
\hline $\begin{array}{l}\text { Total income for } \\
2 \text { years }(\$)\end{array}$ & 28,100 & 25,895 & $2,205^{* *}$ & .16 & 744 \\
\hline $\begin{array}{l}\text { Number of material } \\
\text { hardships }\end{array}$ & 1.96 & 2.13 & -.16 & -.12 & 585 \\
\hline
\end{tabular}

control group. There were no program-control differences in the total number of material hardships reported (see Table 4), but significantly fewer program group members reported periods without health insurance $($ program $=43.9 \%$; control $=53.6 \%)$.

\section{Child Care}

Although some members of both program and control groups had access to public subsidies for child care, $59 \%$ of the program group members received child care assistance from any source, including New Hope, compared to $41 \%$ of the control group. New Hope participants also had lower out-of-pocket costs for child care than did control group parents (Bos et al., 1999). At the 24-month survey, program families had paid about $\$ 25$ less than control families for child care in the prior month.

We expected that the child-care subsidy would permit New Hope participants to use more formal child care (i.e., center-based care and supervised after-school programs) than controls. This in fact happened. Program children spent almost twice as many months in center-based care (for preschool- and school-aged children) and more than twice as many months in school-based extended day care than did control children (see Table 5). There were no programcontrol differences in parent-reported adult-to-child ratios or group sizes. There were no program effects on the use of home-based care.

Although program effects on formal care use occurred for both boys and girls, there were significant sex differences in treatment impacts for center-based $(H T=5.16, p<.05)$ and extended day care $(H T=$ $4.37, p<.05)$. Center-based care was used more for both boys and girls in the program group than in the control group, but the difference was larger for girls. The program-control difference in extended day care was significant for boys, but not for girls, largely because program families used it much more for boys than for girls (see Table 5).

\section{Out-of-School Activities}

For older children, we expected that increased income and child-care subsidies might lead to more participation in adult-supervised after-school activities. Both parents and children were asked how often the child participated in five activities that were structured or supervised by an adult. Parents in the program group reported higher frequencies of participation in these activities for their 9- to 12-year-old children than did parents in the control group. According to reports by 9 - to 12 -year-old children, there 
Table 5 Impacts on Months in Different Forms of Child Care Over Two Years

\begin{tabular}{lcccccr}
\hline & \multicolumn{2}{c}{ Group } & & & \\
\cline { 2 - 3 } Outcome & Program & Control & Difference & $\begin{array}{c}\text { Effect } \\
\text { Size }\end{array}$ & $N$ \\
\hline Formal care & 9.17 & 6.27 & $2.90^{* *}$ & .31 & 902 \\
$\quad$ Head Start & 1.67 & 1.93 & -.26 & -.05 & 902 \\
Center-based care & 6.00 & 3.20 & $2.80^{* *}$ & .35 & 902 \\
$\quad$ Boys & 5.55 & 3.96 & $1.58^{+}$ & .20 & 472 \\
$\quad$ Girls & 6.31 & 2.41 & $3.89^{* *}$ & .48 & 430 \\
School-based extended day care & 1.87 & .70 & $.90^{* *}$ & .21 & 902 \\
$\quad$ Boys & 2.28 & .78 & $1.49^{* *}$ & .35 & 472 \\
$\quad$ Girls & .99 & .69 & .30 & .07 & 430 \\
Any other program & .77 & .83 & -.06 & -.01 & 902 \\
Home-based care & 8.65 & 9.28 & -.62 & -.07 & 902 \\
\hline
\end{tabular}

${ }^{*} p<.05 ;{ }^{* *} p<.01 ;^{+} p<.10$. All two-tailed.

were not significant treatment differences for total frequency of organized activities, but program group children reported more participation in clubs and youth groups in the past week and in the last year than did control children (see Table 6). There were no treatment effects on frequency of engaging in unsupervised activities (reading, homework, weekday television viewing, or playing sports without a coach), but

Table 6 Impacts on Children's Time Use and Activity Participation during the Past Year

\begin{tabular}{|c|c|c|c|c|c|}
\hline \multirow[b]{2}{*}{ Outcome } & \multicolumn{2}{|c|}{ Group } & \multirow[b]{2}{*}{ Difference } & \multirow{2}{*}{$\begin{array}{c}\text { Effect } \\
\text { Size }\end{array}$} & \multirow[b]{2}{*}{$n$} \\
\hline & Program & Control & & & \\
\hline \multicolumn{6}{|l|}{ Parent report of frequency (6-12 yrs) } \\
\hline \multicolumn{6}{|l|}{ Average frequency of organized activities } \\
\hline Age 6-8 & 2.13 & 2.10 & .02 & .03 & 245 \\
\hline Age 9-12 & 2.56 & 2.31 & $.25^{*}$ & .29 & 299 \\
\hline \multicolumn{6}{|l|}{ Frequency of individual activities } \\
\hline Take lessons & 2.40 & 2.12 & $.28^{*}$ & .20 & 558 \\
\hline Play sports or take lessons with coach & 2.32 & 2.18 & .13 & .09 & 558 \\
\hline Go to religion classes & 2.77 & 2.75 & .02 & .02 & 558 \\
\hline Attend clubs or youth groups & 2.00 & 1.88 & .11 & .09 & 558 \\
\hline Boys & 2.13 & 1.76 & $.37^{*}$ & .29 & 279 \\
\hline Girls & 1.91 & 1.96 & -.05 & -.04 & 279 \\
\hline Attend recreational or community center & 2.33 & 2.22 & .11 & .07 & 558 \\
\hline Boys & 2.48 & 2.14 & $.34^{+}$ & .24 & 279 \\
\hline Girls & 2.20 & 2.29 & -.10 & -.07 & 279 \\
\hline Average frequency of household chores & 2.61 & 2.73 & -.12 & -.13 & 559 \\
\hline \multicolumn{6}{|l|}{ View television (hours / day) } \\
\hline Weekdays & 7.64 & 7.44 & .20 & .07 & 913 \\
\hline Weekends & 6.26 & 5.87 & $.39^{* *}$ & .18 & 913 \\
\hline \multicolumn{6}{|l|}{ Child report of past year (9-12 yrs) } \\
\hline Total number of organized activities & 2.6 & 2.4 & .2 & .14 & 287 \\
\hline Take lessons $(\%)$ & 53.3 & 53.7 & -.4 & 0 & 287 \\
\hline Play sports or take lessons with coach $(\%)$ & 52.5 & 60.2 & -7.7 & -.15 & 287 \\
\hline Go to religion classes $(\%)$ & 49.9 & 49.7 & .2 & 0 & 287 \\
\hline Attend clubs or youth groups $(\%)$ & 40.6 & 30.7 & $9.8^{*}$ & .20 & 287 \\
\hline Attend recreational or community center $(\%)$ & 53.3 & 49.9 & 3.4 & .07 & 287 \\
\hline Boys & 63.4 & 47.1 & $16.3^{+}$ & .32 & 138 \\
\hline Girls & 43.7 & 52.8 & -9.1 & -.18 & 148 \\
\hline
\end{tabular}

${ }^{*} p<.05 ;{ }^{* *} p<.01 ;{ }^{+} p<.10$. All two-tailed. 
program group children watched more television on weekends than did controls (see Table 6).

The impact of the program on total structured activity participation did not differ by child sex, but the effects of treatments on boys and girls did differ for participation in clubs and youth groups (parent report, $H T=3.41, p<.10)$ and for going to recreation or community centers (parent report, $H T=3.31, p<.10$, and child report, $H T=3.90, p<.05)$. In separate analyses of boys and girls, the program-control differences were significant for boys, but not for girls (Table 6).

Although girls did more household chores than boys, neither participation in household chores (including sibling care) nor the total frequency of engaging in activities with an adult varied by treatment.

\section{Health Care}

Adult program members were less likely than controls to have periods without health insurance (Bos et al., 1999), but there were no differences in the number of children who were insured. There were also no program effects on any of the indicators of health care for children.

\section{Impacts on Adult Psychological Well-Being and Parenting}

The third research question concerned impacts on parents' psychological well-being, parenting, and parent-child relationships.

\section{Psychological Well-Being}

Changes in employment and income were expected to influence parents' psychological well-being in positive ways (e.g., greater self-esteem and mastery, greater agency and feeling of achieving goals, less depression, more feeling of social support, fewer worries about finances), but some negative outcomes were also considered possible (e.g., stress, time pressure). In fact, there were some significant favorable program impacts: greater "hope" (agency and pathways to goals), lower stress, and more social support, but program group members also reported more time pressure. The results are shown in Table 7 . There were no program impacts on worries about finances, self esteem, mastery, or depression.

\section{Parenting and Parent-Child Relationships}

There were no overall treatment effects on parenting as perceived by the parent and the child, with one exception that was not in the predicted direction. New Hope parents had lower minimum standards for their children's educational achievement than did control parents (program group mean $=3.0$, control mean $=3.2, p<.10$, effect size $=-.14$ ).

Boys in New Hope families perceived their relationship with their parent as more positive than did boys in the control group (program group mean = 4.53 , control mean $=4.39, p<.10$, effect size $=.25$ ). Girls in New Hope families were less likely than girls in control families to think their parent expected them to attend college (program group mean $=4.1$, control mean $=4.5, p<.05$, effect size $=-.40)$; boys in New Hope families were slightly, though not significantly, more likely to think their parent expected them to attend college (program group mean $=4.4$, control mean $=4.1$, ns, effect size $=.27$ ).

As with employment, program impacts on parent-

Table 7 Impacts on Parents' Psychological Well-Being

\begin{tabular}{lrrrrrr}
\hline & \multicolumn{2}{c}{ Group } & & & \\
\cline { 2 - 3 } Outcome & Program & Control & Difference & $\begin{array}{c}\text { Effect } \\
\text { Size }\end{array}$ & $n$ \\
\hline Rosenberg Self-Esteem Scale & 17.61 & 17.41 & .20 & .06 & 570 \\
Pearlin Mastery Scale & 3.09 & 3.09 & -.01 & -.01 & 570 \\
CES-D depressive symptoms & 16.84 & 16.96 & -.12 & -.01 & 573 \\
State Hope Scale & 2.95 & 2.85 & $.10^{*}$ & .18 & 570 \\
Social support & & & & $.11^{* *}$ & .28 & 590 \\
$\quad$ Practical advice $(\%$ yes) & .30 & 0.19 & $.16^{* *}$ & .37 & 590 \\
Emotional support (\% yes) & .33 & 0.17 & $.17^{*}$ & .19 & 575 \\
Time pressure & 3.85 & 3.68 & $-7.50^{+}$ & -.14 & 588 \\
Stressed much or all of the time $(\%)$ & 46.85 & 54.39 & -.04 & -.03 & 590 \\
Financial worry & 2.92 & 2.96 & & &
\end{tabular}

${ }^{*} p<.05 ;{ }^{* *} p<.01 ;{ }^{+} p<.10$. All two-tailed. 
ing differed according to parents' employment status at baseline. Among parents employed full-time at random assignment, New Hope significantly increased parental warmth (program group mean = 4.69 , control mean $=4.42, p<.10$, effect size $=.27$ ) and parent-reported monitoring of the focal child's activities (program group mean $=3.72$, control mean $=$ $3.59, \mathrm{p}<.10$, effect size $=.31)$.

\section{Additional Tests of Effects on Academic Performance and Social Behavior}

To assure that the surprisingly large and genderbased differential program impacts on teacherreported child achievement and social behavior were robust, we undertook several additional analyses. To locate experimental impacts in the distribution of children's achievement and problem behavior, we estimated a series of quantile regressions (Koenker \& Basset, 1982; Rogers, 1993) that provided estimates of program impacts at the 10th, 25th 50th (median), 75th and 90 th percentiles of the teacher-reported outcome distributions. The OLS regression results already presented in Table 3 show program impacts at the mean of the outcome distributions; it is readily conceivable that these impacts may average together larger effects at one end of the distribution with smaller or even negative impacts at the other.

The possible effects of differential nonresponse among families who were eligible for the survey or signed permission forms for the teacher interviews, or among the teachers themselves, led us to estimate sample-selection models (Greene, 1981; Heckman, 1979). These two-stage models consist of: (1) estimating a probit model in which a dichotomous indicator of the likelihood of obtaining a teacher report for each age-eligible child is related to baseline demographic measures and experimental/control status; and (2) using a transformation of the density of this likelihood (Mills ratio) as an additional independent variable in the second-stage child outcome equation. The second-stage estimates provide both a sample selection-adjusted estimate of program impacts and an estimate of the effect and statistical significance of the Mills ratio sample-section factor. A significant coefficient on the Mills ratio indicates that selection bias is present in the model.

Results for the teacher reports of academic

Table 8 Robustness Tests of New Hope Impacts on Selected Teacher Reports

\begin{tabular}{|c|c|c|c|c|c|c|}
\hline & \multicolumn{3}{|c|}{ Boys } & \multicolumn{3}{|c|}{ Girls } \\
\hline & \multicolumn{3}{|c|}{ Standard } & \multicolumn{3}{|c|}{ Standard } \\
\hline & Coefficient & Error & $n$ & Coefficient & Error & $n$ \\
\hline \multicolumn{7}{|l|}{ Academic Achievement } \\
\hline Ordinary least squares regression estimates & $.33^{*}$ & .15 & 208 & .12 & .15 & 208 \\
\hline \multicolumn{7}{|l|}{ Quantile regression estimates } \\
\hline 10th percentile & $.48^{+}$ & .28 & 208 & .01 & .23 & 208 \\
\hline 25th percentile & $.63^{* *}$ & .21 & 208 & .19 & .24 & 208 \\
\hline 50th percentile & $.46^{*}$ & .20 & 208 & .02 & .24 & 208 \\
\hline 75th percentile & $.44^{+}$ & .25 & 208 & .23 & .24 & 208 \\
\hline 90th percentile & .31 & .21 & 208 & .14 & .20 & 208 \\
\hline Sample selection-adjusted regression estimates & .31 & .21 & 208 & .14 & .20 & 208 \\
\hline Mills ratio & -.18 & .80 & 208 & -.16 & 2.26 & 208 \\
\hline \multicolumn{7}{|l|}{ Externalizing Problem Behavior } \\
\hline Ordinary least squares regression estimates & $-.51^{* *}$ & .15 & 208 & $.27^{\dagger}$ & .14 & 208 \\
\hline \multicolumn{7}{|l|}{ Quantile regression estimates } \\
\hline 10th percentile & -.29 & .23 & 208 & .10 & .13 & 208 \\
\hline 25th percentile & $-.42^{*}$ & .21 & 208 & .14 & .17 & 208 \\
\hline 50th percentile & $-.59^{+}$ & .25 & 208 & .16 & .18 & 208 \\
\hline 75th percentile & $-.44^{+}$ & .23 & 208 & .25 & .28 & 208 \\
\hline 90th percentile & $-.53^{*}$ & .24 & 208 & .44 & .33 & 208 \\
\hline Sample selection-adjusted regression estimates & $-.52^{*}$ & .21 & 208 & $.31^{*}$ & .19 & 208 \\
\hline Mills ratio & -.27 & .83 & 208 & -1.00 & 2.73 & 208 \\
\hline
\end{tabular}

Note: Dependent variable has been divided by the whole sample standard deviation. Mills ratio tests for significance of selection bias due to the probability of response for the teacher surveys (Greene, 1981; Heckman, 1979).

${ }^{*} p<.05 ;{ }^{* *} p<.01{ }^{+} p<.10$. All two-tailed. 
achievement and externalizing behavior problems are shown in Table 8. To facilitate comparisons with impacts shown in Table 3, we have standardized dependent variables by dividing by the whole-sample standard deviation.

Taking the academic achievement outcome as illustrative, the first row of Table 8 reproduces the results from Table 3 on the experimental impact as estimated by OLS regression. The next set of rows shows experimental impacts at various points in the achievement distribution. For boys, these impacts are roughly similar in magnitude, although not always statistically significant, at all tested points of the distribution. Significant impacts emerge for none of the tested points in the girls' distribution. Hypothesis tests did not yield significant differences among these percentile scores for either boys or girls. Thus, we conclude that the program impacts on achievement shown in Table 3 hold for both high- and low-achieving boys and for neither high- nor low-achieving girls.

For neither boys nor girls do sample selection adjustments alter the estimated impacts on academic achievement appreciably and for neither group is the coefficient on the Mills ratio close to conventional levels of statistical significance.

These two sets of adjustments produced similarly robust results for teacher reports of boys' externalizing behavior: program effects appear in nearly all tested points of the distribution and sample-selection adjustments have no appreciable effect. In the case of girls, there is some tendency for the perverse impacts of the program to be greater among those at the high end of the problem-behavior distribution and for sample-selection adjustments to produce somewhat larger program impacts. Like academic achievement, however, tests indicated that the percentile coefficients did not differ significantly one from the other.

Similar regressions were estimated for internalizing behavior, total problem behavior scores, and positive behavior scores (results not shown). In no case did sample selection-adjusted impacts differ appreciably from the impact estimates shown in Table 3. Impacts were broadly similar across the distributions for boys and girls. A possible (although statistically insignificant) exception for girls was that there was a noticeable perverse program impact on increased internalizing problem behaviors among girls rated by teachers as low in such problem behaviors.

\section{DISCUSSION}

On the whole, boys in New Hope program families were faring better than were those in control families. Compared to the control group, boys in New Hope families were making better academic progress, had better classroom behavior skills, had higher occupational aspirations and educational expectations, and displayed more positive social behavior in conjunction with fewer behavior problems. The random assignment experimental design assures that these differences can be attributed to the New Hope treatment rather than to selection factors.

Not only were the program impacts on several important child outcomes statistically significant, but the effect sizes were at a level considered socially significant (Cohen, 1988). Teacher ratings of boys' overall positive and problem behaviors had effect sizes of approximately .50 , indicating that the average boy in the New Hope group scored above (for positive behavior) or below (for behavior problems) $69 \%$ of the control group boys. For academic performance and aspirations, the effect size of .33 on school performance indicates that the average boy in New Hope scored above $63 \%$ of the boys in the control group. Effects approximating one third to one half of a standard deviation could make an important difference in the child's current level of functioning and could establish a pathway to better educational attainment and fewer deviant behaviors in the future.

The impacts on child outcomes are particularly persuasive because they appeared on measures obtained from multiple sources. Teachers were given no information about children's participation in New Hope or other interventions, so the program-control group differences on the teacher ratings are unlikely to have been affected by knowledge of the intervention. Impacts also occurred for answers that children themselves provided. Measures obtained from parents, who were the most likely to be affected by their knowledge of the New Hope treatment and the evaluation design, showed fewer treatment differences than did measures completed by teachers and children. In short, the program impacts are real, and they are large enough to be socially significant.

The random assignment experimental design permits us to infer that the New Hope treatment as a whole played a causal role in the impacts on children and the contexts we measured. The only difference between the program and control groups was the random assignment of a parent to the New Hope treatment. Because children were not the direct recipients of New Hope, its effects on them must have been indirect consequences of some or all of its features, and because the treatment was a combination of interventions that were used in different ways by different families, it is difficult to determine which elements or combination of elements in the program were responsible for these effects. 
One way of understanding how the New Hope treatment was translated into consequences for children is to examine the magnitude of treatment effects on the contextual and family variables proposed as potential mediators. This approach uses the power of the experimental design because impacts on these variables can be attributed to the New Hope treatment. Our conceptual model included two sets of contextual variables: changes in availability and use of family resources, including parent time at home, income, child care, and out-of-home activities, and changes in parent-child relationships resulting from parents' psychological well-being. The data provide more support for family resource changes than for family interaction and parenting changes.

Child care was a major resource provided by New Hope; almost half of the parents in the treatment group used the subsidy. New Hope parents used center-based child care for both preschool and elementary school children, as well as extended-day care in schools, more than did control parents. Although we have little information on the quality of care in these settings, there is some evidence that center-based care, on average, is more likely than home-based care to enhance both academic and social skills (Lamb, 1997). Similarly, school-based extended-day care for elementary school children can contribute to school performance, particularly for boys, partly because it provides a setting for tutoring, completing assignments, and engaging in a variety of activities (Pierce et al., 1999; Posner \& Vandell, 1994, 1999).

Organized activities during nonschool hours constitute another potential means by which children in program families acquired social and academic skills. As children move through the years of middle childhood (from about 6 to 12 years), they achieve increasing autonomy and independence from adult supervision. Organized sports, recreation centers, clubs, and lessons all can provide structure, opportunities for learning and practicing skills, supervised peer interaction, and contact with adults. The relatively large effect of New Hope on children's participation in structured activities (formal child care and structured out-of-school activities) points toward out-of-home activities as one pathway by which the program influenced children's academic and social functioning.

New Hope also led to improved family income and to increased parent employment. Income may have provided a range of resources for children; parents often expressed delight at being able to buy toys or shoes that their children really wanted. Although employment took parents away from home, it did not appear to result in less time with children.
Parenting is the other major avenue by which New Hope was expected to convey impacts to children. New Hope had positive effects on those aspects of parents' psychological well-being that seem to be most responsive to changes in context or economic circumstances, but not on more stable personality dispositions. These program effects on well-being did not lead to greater warmth, discipline, or aspirations for children. For the $30 \%$ of the sample who were employed full time when they entered the program, there were some positive impacts on warmth and monitoring. If parenting were primarily responsible for the impacts on children, one would expect child impacts to be concentrated in this subgroup, but that was not the case. The program impacts on children were at least as large, and often larger, for families who were not working full time at baseline, and there were almost no significant interactions of treatment with baseline employment for child outcomes (cf. Bos et al., 1999).

One reason for the limited impacts on parenting could be the brevity and limitations of the measures. Although several of the measures of parent wellbeing (e.g., depression) are well-established scales with good validity and reliability, thus imparting confidence in the null results, the brief self-report measures of parenting may have been insufficiently sensitive to detect treatment effects.

A second major question arising from these results is why the impacts occurred primarily for boys. Although we expected that gender might be important, explanations of the stronger positive effects for boys are largely post hoc. Our analyses showed no evidence of different impacts on parent-reported parenting practices for boys and girls, but parents had more optimistic expectations about future education for their boys than for their girls, and children perceived those differences. Program boys also perceived their relations with their parents to be more positive than did control boys. Boys in New Hope families were more likely than boys in control families to be in extended day care and to participate in some organized out-of-school activities, but girls in program families took more lessons than did control girls. Contrary to our expectations, however, the program did not lead to greater household or sibling-care responsibilities for girls or boys.

One explanation for the differential impacts may be boys' greater vulnerability to or risk of academic and behavior problems in the elementary years. Ethnographic interviews (Weisner et al., 1999) among a randomly selected subsample of program and control families suggested that parents were especially worried about their boys becoming involved in delinquent activity, a worry that appears justified in light 
of the fact that control boys had considerably lower school performance, lower positive behavior, and more behavior problems than did control group girls. Program parents may have made more efforts and invested more resources in insuring that boys had alternatives to hanging out with unsupervised peers after school. The supervised contexts may have been particularly effective because of boys' vulnerability when they are not supervised.

A second possible explanation for the gender difference in program impacts is that boys and girls responded differently to the role models provided by their parents. As about $90 \%$ of the parents in our sample were women, girls may have used their participating parents as role models more than did boys. Overall, New Hope led boys and their parents to have higher aspirations for the child's future, but for girls and their parents, it had no effect or led to lowered aspirations. For these low-income families, the realities of low-wage employment for women may have become more apparent to New Hope parents and their daughters, whereas sons (and their mothers) may not have considered their mothers' employment experiences as relevant to their own futures. Similarly, girls' more frequent behavior and discipline problems at school may indicate increased assertiveness as a response to their mothers' active efforts to improve their lives. The fact that this effect occurred primarily for girls at the high end of the externalizing distribution suggests, however, some possible problematic effects of participation for girls with high levels of externalizing problems.

Whatever the reasons, the combination of circumstances brought about by New Hope led to improved school performance and social behavior for boys. This finding is robust. An intervention that significantly reduces antisocial behavior and improves school performance for boys living in poor families could produce important long-term benefits. Many children in New Hope families are statistically at risk for delinquency and school failure as they approach adolescence. By definition, their families are poor; most are ethnic minorities and most are headed by single mothers. If the experiences provided through New Hope can redirect young boys' trajectories toward better school performance, more competent social behavior, and fewer problems with behavior control, the odds of school completion and socially competent adolescent development will be increased.

Access to formal child care, extended day care in schools, and structured out-of-school activities appears to be an important path by which the New Hope impacts on children occurred. Public policy can readily increase availability of child care, after-school activities, and other opportunities for supervised, structured activities for children; these may, in turn, significantly alter developmental trajectories for children in low-income families.

\section{ACKNOWLEDGMENTS}

This paper summarizes an evaluation conducted by Manpower Demonstration Research Corp. (MDRC) under a contract with the New Hope Project, Inc. and in collaboration with the MacArthur Network on Successful Pathways Through Middle Childhood. It was supported by the John D. and Catherine T. MacArthur Foundation, the Helen Bader Foundation, the Ford Foundation, the State of Wisconsin Department of Workforce Development, the William T. Grant Foundation, the Annie E. Casey Foundation, and the National Institute of Child Health and Human Development (HD36038). The authors are grateful to Julie Kerksick, Sharon Schulz, and Tom Back of the New Hope, Inc. staff, the New Hope Board of Directors, and the New Hope National Advisory Board for their invaluable advice and support for the project. They also thank Carolyn Eldred and Anne Sweeney of MDRC; Westat Inc., under the direction of David Maklan and Alexa Fraser; Marika Ripke, David Casey, Nancy Jennings, Edna Henderson, and Deborah Linebarger at the University of Texas-Austin, and Eboni Howard at Northwestern University for their contributions to data collection and analysis. The authors thank the participating families and children for their time and interest.

\section{ADDRESSES AND AFFILIATIONS}

Corresponding author: Aletha C. Huston, University of Texas, Department of Human Ecology, GEA 117/ A2700, Austin, TX 78712; e-mail: achuston@mail. utexas.edu. Robert Granger and Ana Ventura are at Manpower Demonstration Research Corp., New York, NY; Johannes Bos is at Manpower Demonstration Research Corp., San Francisco, CA; Vonnie McLoyd is at the University of Michigan, Ann Arbor; Rashmita Mistry is at the University of North Carolina, Chapel Hill; Danielle Crosby is at the University of Texas at Austin; and Greg J. Duncan, Christina Gibson, Katherine Magnuson, and Jennifer Romich are at the Institute for Policy Research, Northwestern University, Evanston, IL.

\section{REFERENCES}

Aber, J. L., Brooks-Gunn, J., \& Maynard, R. (1995). Effects of welfare reform on teenage parents and their children. The Future of Children, 5(2), 53-71. 
Asher, S. R., \& Wheeler, V. A. (1985). Children's loneliness: A comparison of rejected and neglected peer status. Journal of Consulting and Clinical Psychology, 53, 500-505.

Bos, J. M., \& Granger, R. C. (1999, April). Estimating effects of day care use on child outcomes. Paper presented at the biennial meeting of the Society for Research in Child Development, Albuquerque, NM.

Bos, J. M., Huston, A. C., Granger, R. C., Duncan, G. J., Brock, T. W., \& McLoyd, V. C. (1999). New hope for people with low incomes: Two-year results of a program to reduce poverty and reform welfare. New York: Manpower Demonstration Research Corporation.

Brock, T., Doolittle, F., Fellerath, V., \& Wiseman, M. (1997). Creating New Hope: Implementation of a program to reduce poverty and reform welfare. New York: Manpower Demonstration Research Corporation.

Caldwell, B. M., \& Bradley, R. H. (1984). Home observation for measurement of the environment. Little Rock, AK: University of Arkansas Press.

Cassidy, J., \& Asher, S. R. (1992). Loneliness and peer relations in young children. Child Development, 63, 350-365.

Children's Defense Fund. (1994). Wasting America's future: The Children's Defense Fund Report on the costs of child poverty. Boston: Beacon Press.

Cohen, J. (1988). Statistical power analysis for the behavioral sciences (2nd ed.). Hillsdale, NJ: Erlbaum.

Cook, T. D., Church, M. B., Ajanaku, S., Jr. Shadish, W. R., Jeong-Ran, K., \& Cohen, R. (1996). The development of occupational aspirations and expectations among innercity boys. Child Development, 67, 3368-3385.

Desai, S., Chase-Lansdale, P. L., \& Michael, R. T. (1989). Mother or market? Effects of maternal employment on the intellectual ability of 4-year-old children. Demography, 26, 545-562.

Duncan, G. J., \& Brooks-Gunn, J. (Eds.). (1997). Consequences of growing up poor. New York: Russell Sage.

Eccles, J. S., Wigfield, A., \& Schiefele, U. (1997). Motivation to succeed. In N. Eisenberg (Ed.), W. Damon (Series Ed.), Social, emotional, and personality development: Vol. 3. Handbook of child psychology (5th ed., pp. 1017-1096). New York: Wiley.

Friedlander, D., \& Burtless, G. (1995). Five years after: The long-term effects of welfare-to-work programs. New York: Russell Sage.

Golombok, S., \& Fivush, R. (1994). Gender development. New York: Cambridge University Press.

Greenberg, D., Meyer, R. H., \& Wiseman, M. (1993). Prying the lid from the black box: Plotting evaluation strategy for welfare employment and training programs. Madison, WI: University of Wisconsin, Institute for Research on Poverty.

Greene, W. (1981). Sample selection bias as a specification. Econometrica, 49, 795-798.

Gresham, F. M., \& Elliott, S. N. (1990). Social skills rating system manual. Circle Pines, MN: American Guidance Service, Inc.

Gueron, J. M., \& Pauly, E. (1991). From welfare to work. New York: Russell Sage Foundation.

Harter, S. (1985). Manual for the self-perception profile for children. Denver, CO: University of Denver.
Harter, S., \& Pike, R. (1984). The pictorial scale of perceived competence and social acceptance for young children. Child Development, 55, 1969-1982.

Heckman, J. J. (1979). Sample selection bias as a specification. Econometrica, 47(1), 153-161.

Hill, M. S., \& Sandfort, J. R. (1995). Effects of childhood poverty on productivity later in life: Implications for public policy. Children \& Youth Services Review, 17, 91-126.

Hoffman, L. W. (1989). Effects of maternal employment in the two-parent family. American Psychologist, 44, 283-292.

Huber, P. J. (1967). The behavior of maximum likelihood estimates under non-standard conditions. In Proceedings of the Fifth Berkeley Symposium on Mathematical Statistics and Probability (pp. 221-233). Berkeley, CA: University of California Press.

Huston, A. C. (Ed.). (1991). Children in poverty: Child development and public policy. New York: Cambridge University Press.

Huston, A. C., McLoyd, V. C., \& Garcia Coll, C. (1997). Poverty and behavior: The case for multiple methods and levels of analysis. Developmental Review, 3, 376-393.

Klerman, L. (1991). The health of poor children: Problems and programs. In A. C. Huston (Ed.), Children in poverty: Child development and public policy (pp. 136-157). New York: Cambridge University Press.

Koenker, R., \& Bassett, G. (1982). Robust tests for heteroscedasticity based on regression quantiles. Econometrica, 50, $43-61$.

Korbin, J. E. (1992). Introduction: Child poverty in America. American Behavioral Scientist, 35(3), 213-219.

Lamb, M. E. (1997). Nonparental child care: Context, quality, correlates, and consequences. In I. Sigel \& K. A. Renninger (Eds.), W. Damon (Series Ed.), Handbook of child psychology: Vol. 4. Child psychology in practice (5th ed., pp. 73-134). New York: John Wiley.

Mallar, C. D., \& Maynard, R. A. (1981). The effects of income maintenance on school performance and educational attainment. In Equity, human capital, and development (pp. 121-141), JAI Press.

Marshall, N. L., Garcia Coll, C., Marx, F., McCartney, K., Keefe, N., \& Ruh, J. (1997). After-school time and children's behavioral adjustment. Merrill-Palmer Quarterly, 43, 497-514.

Mayer, S. E. (1997). What money can't buy: Family income and children's life chances. Cambridge, MA: Harvard University Press.

Mayer, S. E., \& Jencks, C. (1989). Growing up in poor neighborhoods: How much does it matter? Science, 243, 14411445.

Maynard, R. A., \& Murnane, R. J. (1979). The effects of a negative income tax on school performance: Results of an experiment. The Journal of Human Resources: Education, Manpower, and Welfare Policies, 14, 463-476.

McLoyd, V. C. (1990). The impact of economic hardship on Black families and children: Psychological distress, parenting, and socioemotional development. Child Development, 61, 311-346.

McLoyd, V. C. (1998). Socioeconomic disadvantage and child development. American Psychologist, 53, 185-204. 
McLoyd, V. C., Jayaratne, T. E., Ceballo, R., \& Borquez, J. (1994). Unemployment and work interruption among African American single mothers: Effects on parenting and adolescent socioemotional functioning. Child Development, 65, 562-589.

Medrich, E. A., Roizen, J. A., Rubin, V., \& Buckley, S. (1982). The serious business of growing up: A study of children's lives outside school. Berkeley, CA: University of California Press.

Moore, K. A., \& Driscoll, A. K. (1997). Low-wage maternal employment and outcomes for children: A study. The Future of Children, 7(1), 122-127.

Moore, K. A., Zaslow, M. J., Coiro, M. J., Miller, S. M., \& Magenheim, E. (1995). How well are they faring? AFDC families with preschool-aged children in Atlanta at the outset of the JOBS evaluation: Executive summary. Washington, DC: Department of Health and Human Services.

Nakeo, K., \& Treas, J. (1990). Computing 1989 occupational prestige scores. (Methodological Report. General Social Survey No. 70). Irvine, CA: University of California, Department of Sociology.

NICHD Early Child Care Research Network. (2000). The relation of child care to cognitive and language development. Child Development, 71, 960-980.

Parcel, T. L., \& Menaghan, E. G. (1997). Effects of low-wage employment on family well-being. Future of Children, 7(1), 116-121.

Pearlin, L. I., Lieberman, M. A., Meneghan, E. G., \& Mullan, J. T. (1981). The stress process. Journal of Health $\mathcal{E}$ Social Behavior, 22(3), 337-356.

Pela, O. A., \& Reynolds, C. R. (1982). Cross-cultural application of the Revised Children's Manifest Anxiety Scale: Normative and reliability data for Nigerian primary school children. Psychological Reports, 51(3), 1135-1138.

Pettit, G. S., Bates, J. E., Dodge, K. A., \& Meece, D. W. (1999). The impact of after-school peer contact on early adolescent externalizing problems is moderated by parental monitoring, perceived neighborhood safety, and prior adjustment. Child Development, 70, 768-778.

Phillips, D. P., \& Bridgman, A. (Eds.). (1995). New findings on children, families, and economic self-sufficiency. Washington, DC: National Academy Press.

Pierce, K. M., Hamm, J. V., \& Vandell, D. L. (1999). Experiences in after-school programs and children's adjustment in first-grade classrooms. Child Development, 70, 756-767.

Posner, J. K., \& Vandell, D. L. (1994). Low-income children's after-school care: Are there beneficial effects of afterschool programs? Child Development, 65, 440-456.

Posner, J. K., \& Vandell, D. L. (1999). After-school activities and the development of low-income urban children: A longitudinal study. Developmental Psychology, 35, 868-879.

Quint, J. C., Bos, J. M., \& Polit, D. F. (1997). New chance: Final report on a comprehensive program for young mothers in poverty and their children. New York: Manpower Demonstration Research Corporation.

Quint, J. C., Polit, D. F., Bos, J. M., \& Cave, G. (1994). New Chance: Interim findings on a comprehensive program for dis- advantaged young mothers and their children. New York: Manpower Demonstration Research Corporation.

Radloff, L. (1977). The CES-D Scale: A self-report depression scale for research in the general population. Applied Psychological Measurement, 1(3), 385-401.

Reynolds, C. R., \& Richmond, B. O. (1985). Revised children's manifest anxiety scale manual. Los Angeles, CA: Western Psychological Services.

Rogers, W. H. (1993). Sg11: Calculation of quantile regression standard errors. Stata Technical Bulletin Reprints, 3, $16-19$.

Rosenberg, M. (1979). Rosenberg self-esteem scale. New York: Basic Books.

Rowe, D. C., \& Rodgers, J. L. (1997). Poverty and behavior: Are environmental measures nature and nurture? Developmental Review, 17, 358-375.

Salkind, N. J., \& Haskins, R. (1982). Negative Income Tax: The impact on children from low-income families. Journal of Family Issues, 3(2), 165-180.

Snyder, C. R., Sympson, S. C., Ybasco, F. C., Borders, T. F., Babyak, M. A., \& Higgins, R. L. (1996). Development and validation of the state Hope scale. Journal of Personality and Social Psychology, 70, 321-335.

Statistics Canada. (1995). Self-sufficiency project: Self complete questionnaire, parents. Montreal: Statistics Canada.

Weisner, T. S., Bernheimer, L., Espinosa, V., Gibson, C., Howard, E., Magnuson, K., Romich, J., Syam, D., \& Lieber, E. (1999, April). From the living rooms and daily routines of the economically poor: An ethnographic study of the New Hope effects on families and children. Paper presented at the meeting of the Society for Research in Child Development, Albuquerque, NM.

White, H. (1980). A heteroscedasticity-consistent covariance matrix estimator and a direct test for heteroscedasticity. Econometrica, 48, 817-830.

White, H. (1982). Maximum likelihood estimation of misspecified models. Econometrica, 50, 1-25.

Wright, J. C., \& Huston, A. C. (1995). Effects of educational TV viewing of lower income preschoolers on academic skills, school readiness, and school adjustment one to three years later. Lawrence, KS: Center for Research on the Influences of Television on Children.

Yoshikawa, H. (1999). Welfare dynamics, support services, mothers' earnings, and child cognitive development: Implications for contemporary welfare reform. Child Development, 70, 779-801.

Zaslow, M. J., \& Eldred, C. A. (Eds.). (1998). Parenting behavior in a sample of young mothers in poverty: Results of the New Chance observational study. New York: Manpower Demonstration Research Corp.

Zaslow, M. J., \& Emig, C. A. (1997). Welfare to Work. The Future of Children, 7(1), 110-115.

Zaslow, M. J., Rabinovich, B. A., \& Suwalsky, J. T. D. (1991). From maternal employment to child outcomes: Preexisting group differences and moderating variables. In J. V. Lerner \& N. L. Galambos (Eds.), Employed mothers and their children (pp. 237-282). New York: Garland. 